\title{
The Pocket Mouse in Saskatchewan
}

\author{
by ROBERT W. NERO, Saskatchewan Museum of Natural History
}

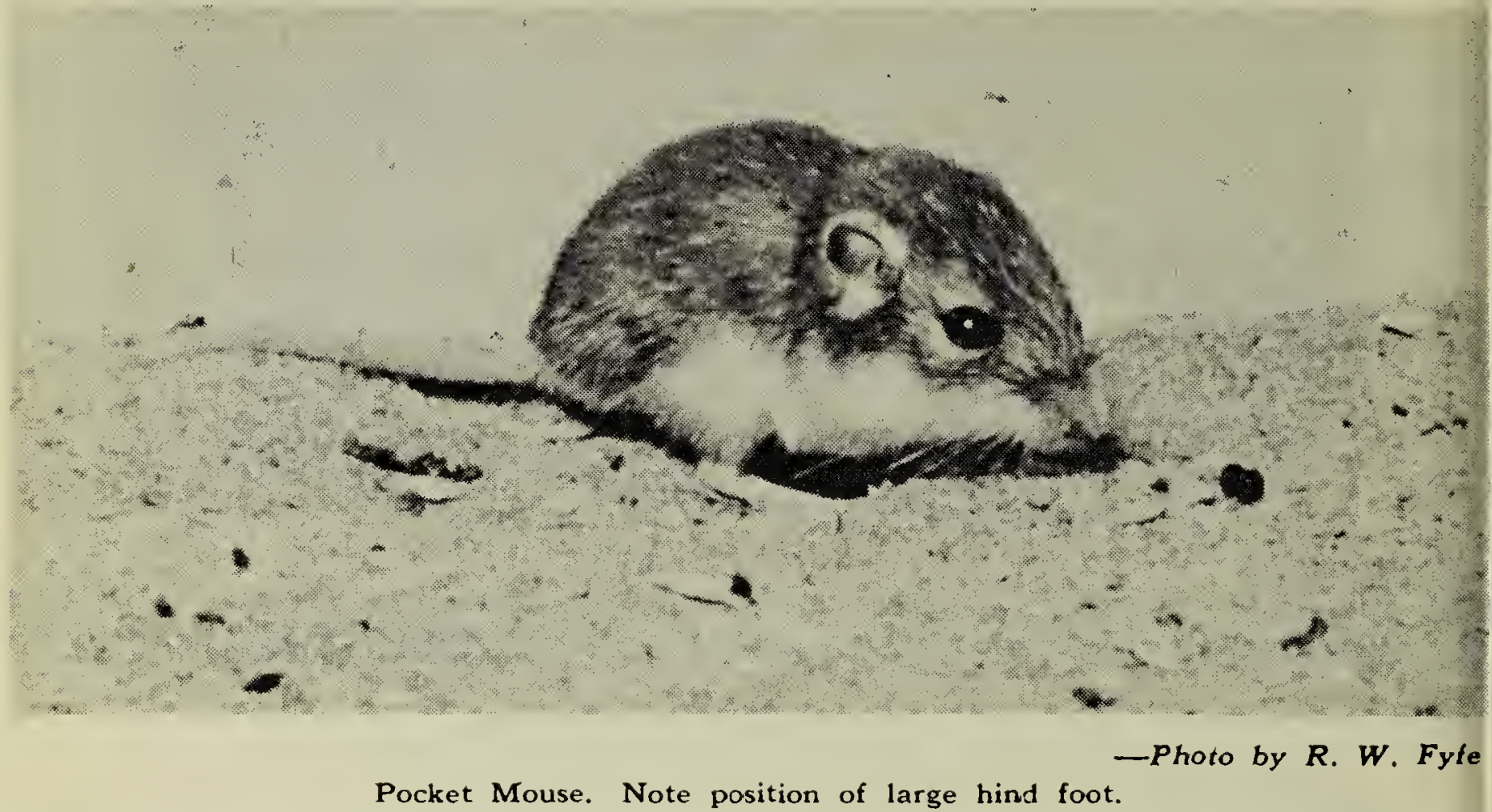

The occurrence of a species of Pocket Mouse (Perognathus fasciatus) in Saskatchewan has been known since 1925 when a specimen was collected at Baildon. Others have been taken since then at several points within the province (see below) but no official account of their occurrence here has yet appeared in the literature outside of brief mention of a recent capture made at Sceptre (Nero and Fyfe 1956). Their presence in Saskatchewan has long been suspected however by several authors. Criddle (1915) wrote as follows: ". . . probably occurs over much of the territory of southern Manitoba, Saskatchewan and Alberta . . . According to Anderson $(1946: 130)$ this mouse occurred in the "Upper Sonoran and Transition zones of northwestern Wyoming and northwestern South Dakota, western North Dakota and $\epsilon$ astern Montana; northward into southwestern Manitoba (Aweme, Oak Lake, Treesbank, and junction of Antler and Souris Rivers); probably also in parts of southeastern (sic.) Saskatchewan, as the U.S.N.M. has specimens from Frenchman River near the southern Saskatchewan boundary." And Rand (1948) stated: ". . . recorded in Manitoba and ? in Saskatchewan, and is to be expected in southern Alberta." Soper (1946:144) stated: "The species is assumed to range along the southern border of southeastern Saskatchewan, west to the Missouri Coteau... However, it must be extremely scarce in the adjacent Saskatchewan territory, as extensive collecting there has failed to take a single specimen."

Data presently available indicate a much wider distribution than the above reports indicate: specimens are on hand from Baildon (1), Nov. 25, 1925 , A. Norman Bury (evidently the first record); Mortlach (3), Aug. 25, 1928, F. G. Bard, June 5, June 12, 1948, F. Lahrman; Imperial (1) Oct. 13, 1947, Lyle Ehman; Sceptre (12), Sept. 18, 1956; Piapot (1) April 23, 1957, F. G. Bard; Skull Creek (2), June 20, 1957, H. Williams, and Sept. 12, 1957, Steve Mann. These records suggest that this species occurs at least locally across southern Saskatchewan (see figure 1). Our Pocket Mouse has been identified by Dr. R. L. Peterson as Maximilian's Pocket Mouse (Perognathus fasciatus fasciatus).

The presence of Pocket Mice in southern Saskatchew'an adds a further name to the list of species typical of the Upper Sonoran life zone. This animal more than any of the others is adapted for living under arid or semi-arid conditions, being able to exist completely without green vegetation or fresh water, subsisting on seeds and insects soley. The importance of insects in the diet of Pocket 
Mice as suggested by Criddle (1915: 34) has been verified for one species (Perognathus parvus) in California by Jameson (1954:592). As further Evidence of their adaptation to a lesert environment (or to an enironment periodically suffering drought conditions) Bartholomew and Cade (1957) point to their habits of storing food, burrowing and their rapacity for remaining dormant for ong periods. In laboratory exberiments it was possible to induce ong periods of fasting at low emperatures.

These appear to be years of abunlance for Pocket Mice. Eighteen which were collected south of sceptre in the Great Sand Hills (see Blue Jay, 14:107-110) were caught $n$ three nights by hand in the headights of the car or were found dead on the road after our vehicle had bassed by. They were found in the band Hills crossing a road bordered y buckbrush, in an open pasture of are sand and sage plants, and were specially numerous on a weedy road ordered by grass and adjacent to lfalfa and wheat-stubble fields. One pecimen found dead on the road in he latter location still had its cheek ouches full of weed seeds; the right ocket contained 195 seeds, the left 40. All 335 seeds were alike and ave been identified by Mr. L. Bell, askatoon, Dom. Dept. Agri., as notweed (Polygonum exsertum).

One of the Pocket Mice (Peronathus longimembris) is the smal- lest North American rodent; ours is certainly the smallest rodent in Saskatchewan. Specimens taken here are about five inches in total length, are olive-gray on the back and on the sides, and are white beneath. A yellow wash is apparent low on the sides. They can be recognized at once by their external fur-lined cheek pouches which have an opening on both sides of the lower head beside the mouth. Since they are nocturnal one needs to look for them late in the evening or after dark. They prefer rather bare open country with weedy places and make tiny burrcws in the ground. Additional specimens are needed to fill out the incomplete range picture shown by the map.

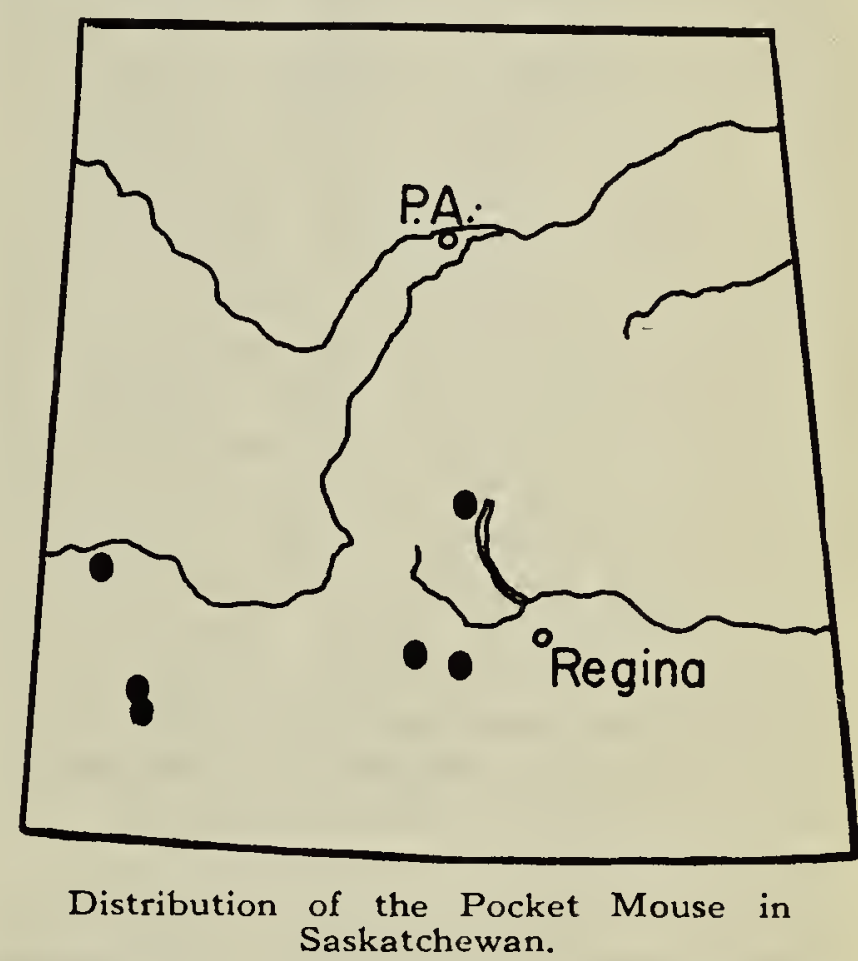

\section{LITERATURE CITED}

NDERSON, R. M.-1946. Catalogue of Canadian recent mainmals. Nat. Mus. Can. Bull. No. 102 ARTHOLOMEW, G A and CADE, T. J.-1957. Temperature regulation, hibernation, and aestivation in the Little Pocket Mouse, Perognathus longimembris. Journ. Mamm., 38:60-72 DLE, S. - 1915. The Banded Pocket Mouse, Perognathus fasciatus Wied. The Ottawa Naturalist, 28:130-134.

AMESON, E. W., Jr.-1954. Insects in the diet of Pocket Mice, Perognathus parvus. Journ. Mamm. 35:592-593.

ERO, R. W. and FYFE, R. W.-1956. Kangaroo Rat colonies found. Blue Jay 14: 107-110. AND, A. L. - 1948. Mammals of the Eastern Rockies and Western Plains of Canada. Natl. Mus. Can. Bull. No. 108.

OPER, J. D.-1946. Mammals of the northern Great Plains along the international boundary in Canada Journ. Mamm., 27: 127-153.

\section{Behaviour of a Captive Pocket Mouse}

by Robert W. Nero, Saskatchewan Museum of Natural Hisitory

A Pocket Mouse (Perognathus fasatus) captured at Sceptre, Sask: on eptember 18, 1956 has been kept ive in a small cage at my home ght up to the present. In addition providing a greait deal of amuseent over this period, keeping the mouse has allowed me to make certain observations which seem worth recording. Its only food througout this period has been Budgie bird seed. It was offered water, apple and celery at first but showed no signs of interest in these. Oddly 